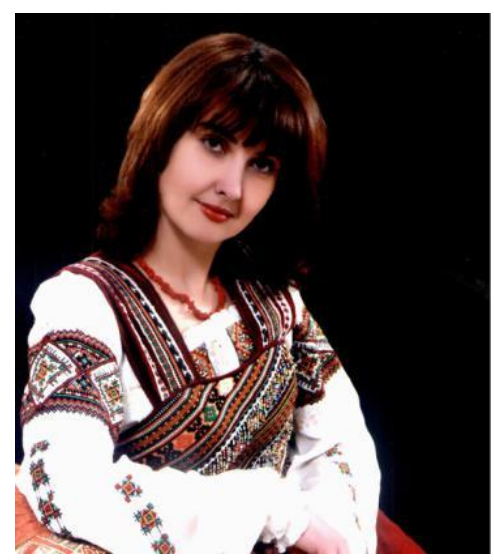

\section{Олександра Качмар,}

доктор фрілософрських наук, професор кафедри фахових методик і технологій початкової освіти, ДВНЗ «Прикарпатський національний університет імені Василя Стефаника» (м. Івано-Франківськ, Україна)

\section{Oleksandra Kachmar,}

Doctor of Philosophy, Professor

of the Department of Professional Methods

and Technologies of Primary Education,

Vasyl Stefanyk Prekarpation National University

(Ivano-Frankivsk, Ukraine)

Ooleksandra75@ukr.net

ORCID ID 0000-0002-2002-4603

\section{Оксана Крицак,}

викладач кафедри англійської мови, Івано-Франківський національний Технічний університет нафтти і газу, (м. Івано-Франківськ, Україна)

\section{Oksana Krytsak,}

Teacher of the Department of English, Ivano-Frankivsk National Technical University of Oil and Gas (Ivano-Frankivsk, Ukraine)

oksana.krytsak@gmail.com

\title{
ПОПЕРЕДЖЕННЯ I ВИРІШЕННЯ КОНФЛІКТІВ У мОЛОДШОМУ ШКІЛЬНОМУ ВІЦІ
}

\begin{abstract}
Анотація. У статті висвітлено основні чинники і причини конфрліктів у навчально-виховному процесі, їх наслідки, вплив на фрізичне і психічне здоров'я учнів, шляхи попередження і подолання.

Сьогодення - це час стресів, хвилювань, страху про завтрашній день. Насиченість сучасного життя конфрліктами, невміння адекватно їх сприймати, відповідно реагувати на них породжують високий потенціал конфліктогенності особистості, що стосується й шкільного життя.

У школі відбувається процес формування особистості дитини. I від того, наскільки успішно здійснюється цей процес, кількість конфліктів між школярами зростає або знижується. Велику роль у запобіганні конфліктів відіграє дисципліна вміння забезпечити дитині необхідну для повноцінного розвитку свободу в рамках розумного підпорядкування встановленому порядку. Метою нашої роботи є вивчення причин конфліктів та найефективніших шляхів їх вирішення.

Перебудова сучасної системи педагогічної діяльності у плані забезпечення різнобічного і гармонійного розвитку особистості вимагає від учителя особливої уваги до учня на переломних етапах його психічного та соціального розвитку. Конфронтація з дітьми, несприятливі умови життя стали звичним явищем, тому конфлікт перманентно спостерігається в шкільному середовищі.

Авторами розглянуті види шкільних конфліктів та їх профілактика в освітньому середовищі.

Ключові слова: конфлікт, навчально-виховний процес, шкільне середовище, профрілактика конфлікту, психічне здоров'я.
\end{abstract}

\section{PREVENTION AND CONFLICT RESOLUTION AT JUNIOR SCHOOL AGE}

Abstract. The problem of conflict is extremely relevant, in recent years the theory and practice of conflict resolution are developing rather quickly. The purpose of the paper is to clarify the concept of conflict, the factors that affect the emergence of conflict situations among pupils of junior school age, the definition of ways to correct behavior to overcome conflicts. The task of the study is to identify the psychological features of the conflict, factors contributing to their occurrence, to consider the types of school conflicts, the main factors and causes of conflict situations in junior pupils. The author used the following 
methods of research: systematization and generalization of philosophical, psychological and pedagogical, scientific and methodological literature on the problem of conflict resolution, empirical methods: generalization, comparison.

The process of forming the child's personality takes place at school. The number of conflicts between schoolchildren increases or decreases depending on how successful this process is. An important role in preventing conflicts is played by discipline which is the ability to provide a child necessary for his development freedom within the framework of reasonable subordination in the established order.

The aimof our work is to study the causes of conflicts and consider the most effective ways of solving hem.

The reorganization of the modern system of pedagogical activity in terms of ensuring the versatile and balanced development of the individual requires a special teacher's attention to the student at the critical stages of his mental and social development.

Confrontation with children, unfavorable living conditions have become commonplace, so the conflict permanently takes place in the school environment.

The authors review the types of school conflict and the ways of their prevention in the educational environment.

Keywords: conflict, educational process, school environment, prevention of conflict, mental health.

\section{ВСТУП}

Постановка проблеми. Життя без конфліктів - зовсім прісне, як їжа без спецій. Кожна людина незалежно від своїх індивідуальних особливостей, професії, посади бере участь у конфлікті або ії туди втягують. Конфлікти виникають впродовж життя людини і ії розвитку, що є результатом зіткнення, межування та зв'язку із зовнішнім світом і безпосередньою участю в ньому. Вони не є чимось неминучим, приреченим долею, а являють собою проблеми і задачі, які ми пробуємо вирішити. Конфлікти не виникають, як грім серед ясного неба, у кожного

з них своя власна історія. Будь-хто з нас може потрапити в незвичну, навіть екстремальну ситуацію. Проте як суспільство, так і особистість розвиваються відповідно до законів діалектики: нове приходить через заперечення старого, а отже, і через конфлікти, які є неминучими і потрібними через зміни.

Говорячи про конфлікт, ми найчастіше асоціюємо його з агресією, погрозами, сварками, і ще гірше - із ворожістю. В результаті цього утвердилася думка, що конфлікт - це небажане явище, і його необхідно, якщо змога, уникати, а якщо він все ж таки виник, то відразу розв'язувати.

Звичайно, конфлікти ускладнюють життя, але саме вони часто стають поштовхом до розвитку: примушують нас рухатися вперед, переглядати існуючий порядок (або безлад), виводити на новий рівень наші взаємини [2].

Аналіз останніх досліджень і публікацій. Проблема конфліктності надзвичайно актуальна, в останні роки теорія і практика розв'язання конфлліктів розвиваються досить швидко. Виник навіть новий напрям, представники якого вивчають дану проблему на стику різних наук, - конфліктологія. Питаннями моральної та психологічної природи конфлікту займаються як окремі науковці, так і науково-дослідні інститути. Зокрема, проблемі агресії та агресивності, конфліктознавству присвятили свої праці такі науковці, як: у філософії Воронкова В. Г., Дзвінчук Д.І., Качмар О.В, Коломієць О.Г, Култаєва М.М., у психології Бех І.Д., Боришевський М.Й., Карпенко З.С.; дослідження зарубіжних учених Дози Р., Томпсона Л., Раппопорта Д., Шерифа М., у соціології роботи Даррендорфа Р., Пірен М. І.

META I ЗАВДАННЯ ДОсЛІДЖЕННЯ. Мета дослідження полягає у з'ясуванні поняття про конфлікт, фактори, що впливають на виникнення конфліктних ситуацій серед учнів молодшого шкільного віку, визначенні шляхів корекції поведінки для подолання конфліктів. У відповідності до мети дослідження були поставлені такі завдання: виявити психологічні особливості конфлікту, фрактори, що сприяють їх виникненню, розглянути види шкільних конфліктів, основні чинники і причини виникнення конфоліктних ситуацій у молодших школярів.

МЕТОДИ ДОСЛІДЖЕННЯ: для досягнення мети і виконання завдань використано такі теоретичні методи:

систематизація та узагальнення фрілософської, психолого-педагогічної, науково-методичної літератури з проблеми вирішення конфліктних ситуацій, метод наукового пошуку, емпіричні методи дослідження: узагальнення, порівняння.

\section{РЕЗУЛЬТАТИ ДОСЛІДЖЕННЯ}

Сучасне життя - це динаміка, це щосекундний рух, в якому все тече та змінюється, і дуже просто піддатись на провокацію конфлікту, який $є$ природним фрагментом людського життя, однією з форм нормальної людської взаємодії. Хоча він, можливо, не найкраща форма цієї взаємодії, проте уникнути його практично неможливо. Тому ще в міфах і легендах, ідеях фрілософів, мислителів та істориків минулих століть подано глибокі зауваження щодо причин різних конфліктів та шляхів їх подолання.

Незважаючи на великий обсяг досліджень, у фрілософії, психології, соціології, етиці досі не вироблено загальноприйнятого визначення природи конфлікту, його сутності, ескалації. У перекладі з латинської мови слово «конфлікт» означає зіткнення [7, с. 141]. Конфлікти між індивідами частіше за все засновані на емоціях і особистій неприязні. Конфрліктний процес, що виник, важко зупинити, це пояснює його кумулятивну природу, тобто кожна агресивна дія призводить до дії у відповідь або відплати, причому більш сильної, ніж первинна.

В умовах конфлікту важко працювати, генерувати нові ідеї, ефективно планувати свій час, оскільки надто багато сил і енергії забирає протистояння. 3 іншого боку, конфлікт допомагає виявити суперечності в колективі, у стосунках та нейтралізувати їх.

Конфрлікт виникає між людьми, школярами, які чимось пов'язані, інколи спільна взаємодія необхідна обом сторонам, а це обставина, яка спонукає їх іти на поступки та враховувати бажання один одного. Конфлікт - це 
нагода відстояти власні інтереси, думки та цінності, що не завжди відбувається мирним шляхом. Для його вирішення повинне бути бажання і можливість досягти згоди та погодитися на компроміс. Спочатку суперечка та вдавання до крайнощів, а потім пошук згоди та компромісу - так виглядає процес конфлікту, це - як вдих і видих [ 5].

Сучасна освіта основний акцент ставить на гуманістичній спрямованості педагогічного процесу. Ставлення до школяра не як до об'єкта навчання й виховання, а як до суб'єкта спілкування потребує розвитку в учня самостійності, самоорганізованості, вміння вступити в діалог з іншою людиною [ 8, с. 24].

У школі діти міркують над типами конфліктів, які виникають у їх спільноті. Учні вивчають способи вирішення конфрліктів ненасильницькими методами, такими, наприклад, як посередництво однолітків.

Під час розв'язання конфліктної ситуації головна освітня мета - це допомогти учням зрозуміти, що конфлікт може бути вирішений різним шляхами. Залучені сторони можуть бути у позиції переможців або переможених, або можуть обидві досягти компромісу. Жодна сторона не повинна відчувати себе переможеною, оскільки це може призвести до нового спалаху конфолікту.

Учитель пояснює учням, що може бути три різних типи подолання конфлікту:

- перемога-перемога: рішення, які дозволяють обом сторонам виграти;

- перемога-поразка: рішення, від яких виграє лише одна сторона за рахунок іншої;

- поразка-поразка: рішення, від якого не виграє жодна сторона.

Учитель наводить приклади різних способів вирішення конфрліктів:

Хлопчи кта дівчинка сваряться за іграшку. Втручається дорослий і пропонує їм гратися іграшкою (наприклад, м'ячем), разом або дає однаковий час на його використання. У виграші вони обоє. Якщо дорослий дає м'яч лише одному з них, звичайно, лише один буде у виграші. Якщо дорослий забирає м'яч, оскільки діти не можуть домовитися, не виграє ніхто. У парах чи групах учні з власного досвіду знаходять інші приклади конфлікту, обговорюють свій досвід конфлікту вдома, або у школі [9].

Як виникає конфлікт? Розглянемо його етапи:

- передконфрліктна ситуація;

- конфрліктна ситуація;

- інцидент;

- вирішення (розв'язання)

- післяконфліктний період.

Конфлікт розвивається тоді, коли стається інцидент (сутичка, непорозуміння). Це буває, наприклад, якщо одна сторона ігнорує інтереси іншої. Якщо ж інша сторона відповідає тим же, то конфлікт з потенційного переростає в актуальний. В основі будь-якого конфлікту лежить конфліктна ситуація. Конфліктною стає така ситуація, в якій закладено суб'єктивні фактори і об'єктивні умови для зіткнення протилежно спрямованих інтересів, думок, позицій суб'єктів. Для усвідомлення учнями причин виникнення конфліктних ситуацій слід запропонувати ігрові вправи, які матимуть навчальний характер [4, с. 211].

Вправа «Стіна конфлікту». Мета: осмислення учнями причин виникнення конфліктних ситуацій. Об'єднання в групи (за допомогою картинок): на аркушах-«цеглинках» написати, що є причиною конфліктних ситуацій: учень-учень, учень-батьки, учень-вчитель. Створюється «Стіна конфрлікту» (підлість, ревнощі, заздрість, жадібність, нещирість, егоїзм, брехня).

Вправа «Мозковий штурм». Які якості потрібні людині для розв'язання конфліктних ситуацій? Діти пишуть свої варіанти відповідей. Проводимо обговорення результату.

Для визначення поняття конфлікту та мирного вирішення варто запропонувати таку процедуру:

1.Слово «конфлікт» записуємо на аркушах, учні отримують два завдання для мозкового штурму:

- записують максимальну кількість виразів та слів, пов'язаних з конфліктом, які спадають їм на думку;

- учні додають ключові слова, пов'язані з конфліктними ситуаціями. Ця

частина виконується без коментарів.

2. Коли в учнів закінчуються ідеї, на іншому аркуші пишеться слово «Мир». Процедура повторюється. Клас обговорює результати. Учням пропонується ілюструвати різні ситуації миру та конфлікту за допомогою малюнків або статей та фотографій з преси [9].

Чим більш раціональним є підхід сторін до конфлікту, тим більше є шансів його вирішення шляхом переговорів та компромісу, а не насильства. Раціональне вирішення конфліктів вимагає від сторін проведення межі між суттю конфлікту та опонентом, а також поваги людської гідності опонента в контексті прав людини [6].

Прояви конфліктності дуже характерні для молодшого шкільного віку, однак мають ситуативний характер і поступово можуть зникнути. Слід підкреслити, що конфлікти стали однією з найскладніших проблем життєдіяльності сучасної школи. Учні, взаємодіючи з дорослими, однолітками, соціально-культурним середовищем, досить часто на різних рівнях і через різні обставини стикаються з конфліктами. Постійно зростає кількість конфліктів у системі «учитель-учень» та «учень-учень». Сьогодні майже нормою стала відсутність позитивних взаємин між педагогом і школярами, зростає емоційна й духовна дистанція між ними; навпаки - падає взаємний інтерес один до одного, знижується мотивація учнів до навчання [5].

Тривалі, нерозв'язані конфлікти негативно впливають на міжособистісні стосунки, соціально-психологічний клімат у шкільному колективі. 
Конфлікт - це суперечність у діалектичному підході до явищ - джерело всякого розвитку. Будь-який конфлікт відразу не переходить у гостру фазу, як правило, він динамічно розвивається. Незалежно від причин виникнення він має чотири фази:

1. Латентна - конфліктність не усвідомлена, проте виникають сумніви щодо надійності й порядності партнера, поступово зникають порозуміння і довіра. Якщо опоненти виявлять бажання порозумітися, вони можуть легко вирішити проблему й повернутися до попередніх стосунків.

2. Демонстративна- розпочинається, коли конфліктуючі сторони незадоволені одне одним. Якщо у латентній фразі опоненти намагалися робити вигляд, що в них усе гаразд, то тепер спілкування відбувається на підвищених тонах, супроводжується сварками. Якщо опоненти дійдуть консенсусу на цій стадії, то можуть легко повернутися до нормального спілкування. Якщо цього не станеться, то конфлікт переходить у наступну фазу.

3. Агресивна - конфліктуючі не спілкуються, уникають одне одного, виношують агресивні плани, часто порушують моральні норми. На цій фразі конфлікт іноді припиняється, але частіше він переходить у завершальну фазу батальну.

4. Батальна -передбачає реалізацію агресивних планів, початок «бойових дій». Опоненти прагнуть перемогти за будь-яку ціну, дискредитуючи інтереси протилежної сторони. Досягти порозуміння на цій фазі практично неможливо.

Тому необхідно вирішувати конфлікт на його початку, коли є ще хоча б найменша можливість повернутися до попередніх відносин з опонентом [7, с. 15].

На думку деяких науковців, можливий ще опісля-конфліктний синдром як психологічний досвід, результат і психічний стан, який відчуває кожна із сторін після виходу із цієї складної ситуації. Часто конфлліктний синдром відбувається у вигляді фрустрації. Це крайня невдоволеність, блокування прагнень, тривале негативне емоційне переживання, що дезорганізує свідомість і діяльність. Фрустрація може розкриватися у вигляді прикрості, озлобленості, повної байдужості до оточення, необмеженого самозвинувачення [1,с.141]. «Не так сталося, як гадалося», - говорить народна приказка. Тому очікування швидких позитивних змін може привести до розчарування й апатії. Звідси порада: не плекати ілюзій, а розраховувати на мудре, мирне вирішення ситуації.

Зрозуміло, що конфлікти деструктивно впливають на його учасників, що призводить до погіршення настрою та емоційного вигорання, негативно позначається на розвитку особистості та фрормуванні почуття недовіри [3].

Подолання конфліктів - це певною мірою навичка, якою можна оволодіти, вміле рішення конфлікту може привести до гармонії, у той час як спроба задавити конфлікт - до агресії. Справедливість вирішення конфліктів $€$ важливим елементом, і це стосується цінностей та культури конфліктної поведінки. В ідеалі конфлікт повинен завершитися ситуацією, в якій виграють обидві сторони. Якщо це неможливо, потрібно зробити так, щоб ніхто не програв, а, навпаки, знайшов компроміс, який забезпечить баланс у поділі переваг і недоліків. Потенційними учасниками конфлікту стають не лише опоненти, які безпосередньо беруть участь у ньому, але також спільнота та середовище в цілому [9].

Серед різних засобів попередження конфлікту не слід забувати про властиве дітям почуття гумору. Будучи дієвим інструментом сприятливого спільного життя чи в сім'ї, чи в шкільному середовищі, гумор, посмішка, сприяють розрядці напруження, що виникає інколи в дитячих взаєминах, є хорошим засобом для того, щоб викликати позитивні відчуття та емоції. Зигмунд Фрейд визнавав, що гумор згладжує суперечності, застерігає від незадоволеності. Гумор об'єднує людей навіть тоді, коли здається, що вже не залишилося жодних сподівань на примирення. Не можна не згадати улюбленого позитивного героя з мультфільму Кота Леопольда, який стверджував: «Друзі, давайте жити дружно».

Отже, вирішення - заключна стадія еволюції конфлікту. За будь-якого виду розвитку конфлікту завдання вчителя полягає в тому, щоб перетворити протидію сторін на взаємодію, деструктивний конфлікт на конструктивний. Для цього слід сприяти адекватному сприйняттю опонентами один одного. Контролюючи емоції, вчитель повинен знизити емоційне напруження у відносинах з учнем, батьком, колегою. Не відповідати на агресію агресією, дати можливість висловитись і вислухати претензії опонента, не робити поспішних висновків і не давати поспішних порад, зуміти переконати опонента, що ви йому не ворог і готові до співробітництва [8, с.26]. Наступним кроком до врегулювання конфлікту $€$ діалог. Це спосіб налагодження комунікації, засіб для обговорення спірних питань і пошуку взаємодомовленості. Під час діалогу бажано виявляти такт і коректність, не перебивати без потреби, не нав'язувати свою думку.

У веденні діалогу опоненти уточнюють відносини, позиції, наміри, цілі один одного. Коли будуть визначені джерело і причина суперечки, то можна переходити до взаємодії, яка є завершальним етапом урегулювання конфлікту. Ключ у тому, яким способом подолати конфлікти: учасники повинні ставитися до них як до навчального інструменту, скеровувати енергію та перетворювати на конструктивність.

За розв'язання конфліктів у дитячому колективі відповідальність лежить на вчителеві, незалежно від характеру конфлікту і ставлення до нього, є він учасником чи посередником. Учитель, класний керівник повинні глибоко вивчити та проаналізувати психологічну ситуацію в колективі, з'ясувати причини виникнення протиріч. Розумна постановка питання зводиться не до повного уникнення конфліктів, а до намагання навчитись правильно вирішувати конфліктні ситуації, робити їх корисними, якщо це можливо [10]. Як вже було вище сказано, конфлікти є невід'ємною частиною нашого життя, звести їх можна до мінімуму, якщо не вимагати від дітей повного конформізму й залежності, якщо 
поблажливо ставитись до індивідуальних особливостей усіх членів родини. Діалог і прагнення зрозуміти одне одного - місток, який поєднує, а не розділяє старше й молодше покоління.

Основною ланкою при розв'язанні педагогічних ситуацій є здійснення їі психологічного аналізу. Вчитель може розкрити причини ситуації, не допустити її переходу у тривалий конфлікт, тобто якоюсь мірою навчитися володіти ситуацією, використовуючи її пізнавальні та виховні фрункції [3].

\section{ВИСНОВКИ ТА ПЕРСПЕКТИВИ ПОДАЛЬШИХ ДОСЛІДЖЕНЬ}

Отже, конфлікт має амбівалентний характер: містить як негативні риси, які призводять до погіршення соціальнопсихологічного клімату у шкільному середовищі та зниження продуктивності праці, так і позитивні сторони, що сприяють розвитку і вдосконаленню його учасників. Конфлікт не можна ліквідувати за допомогою чарівної палички, тим більше конфлікт дитячий, тому що він базується в основному на емоціях, які в дитячому віці надто сильні: вони витісняють голос розуму. Якщо шкільні конфлікти стають нормою, то лікувати треба не психологією, а режимом і дисципліною, без якої немає ладу. Школа без дисципліни, що млин без води. Якщо ми не навчимося безконфліктно жити в шкільному середовищі і знаходити компроміс, то ніколи не звільнимося від конфліктів між учнями та вчителем, між самими учнями. Тут важлива профрілактика, у тому числі й психологічна.

Попередити або послабити конфлікт можна, тільки нейтралізувавши агресивні відчуття і наміри, що є надто складним завданням. Це робота систематична, повсякденна. Найнадійніший спосіб профілактики конфліктів - це створення в сім"ї, класі, в шкільному колективі, в суспільстві в цілому такої морально-психологічної атмосфрери, яка виключала б саму можливість виникнення причин, що призводять до конфрліктів. Досягти цієї високої мети можна тільки внаслідок послідовного здійснення цілого комплексу продуманих заходів щодо зміцнення відносин співпраці та взаємодопомоги між людьми.

\section{СПИСОК ВИКОРИСТАНИХ ДЖЕРЕЛ}

[1] Воронкова В.Г., Беліченко А.Г., Мельник В.В. Етика ділового спілкування: навчальний посібник. Львів: Магнолія. 2006, 2017. С. $141-145$.

[2] Гармаш Л. Психічне здоров'я учнів початкової школи та шляхи його поліпшення / Л. Гармаш, H. Концур, Л. Tовкун. URL: httpwww.social -science.com.ua/ публікація /487.

[3] Гришина Н.В. Психология конфрликта. СПб:Питер, 2006. 464 с.

[4] Експрес-діагностика стійкості до конфліктів / Фетіскін Н. П., Козлов В. В., Майнулов Г. М. Соціально-психологічна діагнос-тика розвитку особистості і малих груп. М., Вид-во Інституту Психотерапії. 2002. С.211-212.

[5] Єременко Л. В. Роль педагога у вирішенні конфліктних ситуацій в учнівському колективі. URL: osvita.ua. Форум педагогіч-них ідей. 2019.

[6] Закон України «Про освіту». URL: https://zakon.rada.gov.ua/laws/show/2145-19

[7] Ільїна Н.М.Конфрлікти в загальноосвітній школі: навчальний посібник. Суми: Університетська книга, 2017. 183 с.

[8] Кириленко А. І. Конфрлікти між учителями та учнями. Способи їх розв'язання. Шкільному психологу. 2011. № 4. С. 24-28.

[9] Рольф Голлоб, Петер Крапф. Навчаємо демократії. Збірник практичних занять з освіти для демократичного громадянства та освіти з прав людини. Вирішення конфліктів. Вправа 8.1., Вправа 8.4. Том VI.

\section{REFERENCES (TRANSLATED AND TRANSLITERATED)}

[1] Voronkova V.Gh., Belichenko A.Gh., Meljnyk V.V. Etyka dilovogho spilkuvannja (Ethics of business communication): navchaljnyj posibnyk. Ljviv: Maghnolija. 2006, 2017. S. 141-145. (in Ukrainian)

[2] Gharmash L. Psykhichne zdorov'ja uchniv pochatkovoji shkoly ta shljakhy jogho polipshennja (Mental health of elementary school students and ways to improve it) / L.Gharmash, N.Koncur, L.Tovkun. URL :httpwww.social -science.com.ua/ publikacija /487. (in Ukrainian)

[3] Ghryshyna N.V. Psykhologhyja konflykta (Psychology of conflict). SPb:Pyter, 2006. 464 s. (in Russian)

[4] Ekspres-diaghnostyka stijkosti do konfliktiv (Express-diagnostics of conflict resistance) / Fetiskin N. P., Kozlov V. V., Majnulov Gh. M. Socialjno-psykhologhichna diaghnostyka rozvytku osobystosti i malykh ghrup. M., Vyd-vo Instytutu Psykhoterapiji. 2002. S.211-212. (in Ukrainian)

[5] Jeremenko L. V. Rolj pedaghogha u vyrishenni konfliktnykh sytuacij v uchnivsjkomu kolektyvi (The role of the teacher in solving conflict situations in the student community). URL: osvita.ua. Forum pedaghoghichnykh idej. 2019. (in Ukrainian)

[6] Zakon Ukrajiny «Pro osvitu» (Law of Ukraine "On Education"). URL: https://zakon.rada.gov.ua/laws/show/2145-19(in Ukrainian)

[7] Iljjina N. M. Konflikty v zaghaljnoosvitnij shkoli (Conflicts in the general school): navchaljnyj posibnyk. Sumy: Universytetsjka knygha, 2017. 183 s. (in Ukrainian)

[8] Kyrylenko A. I. Konflikty mizh uchyteljamy ta uchnjamy. Sposoby jikh rozv'jazannja (Conflicts between teachers and students. Ways of solving them). Shkiljnomu psykhologhu. 2011. № 4. S. 24-28. (in Ukrainian)

[9] Roljf Ghollob, Peter Krapf. Navchajemo demokratiji. Zbirnyk praktychnykh zanjatj z osvity dlja demokratychnogho ghromadjanstva ta osvity z prav ljudyny. Vyrishennja konfliktiv (Teaching democracy. Collection of practical education classes for democratic citizenship and human rights education. Resolving conflicts). Vprava 8.1., Vprava 8.4. Tom VI. (in Ukrainian) 